\title{
Steve Chan, China, the U.S., and the Power- Transition Theory: A Critique
}

London and New York, Routledge, 2008, 197 pp.

\section{Lynn T. White}

\section{OpenEdition}

\section{Journals}

Electronic version

URL: http://journals.openedition.org/chinaperspectives/4789

DOI: $10.4000 /$ chinaperspectives.4789

ISSN: 1996-4617

\section{Publisher}

Centre d'étude français sur la Chine contemporaine

Printed version

Date of publication: 1 April 2009

Number of pages: 109-110

ISSN: 2070-3449

\section{Electronic reference}

Lynn T. White, «Steve Chan, China, the U.S., and the Power- Transition Theory: A Critique », China Perspectives [Online], 2009/1 | 2009, Online since 01 April 2009, connection on 21 September 2020. URL : http://journals.openedition.org/chinaperspectives/4789; DOI : https://doi.org/10.4000/ chinaperspectives.4789

This text was automatically generated on 21 September 2020.

(c) All rights reserved 


\title{
Steve Chan, China, the U.S., and the Power- Transition Theory: A Critique
}

London and New York, Routledge, 2008, 197 pp.

\author{
Lynn T. White
}

1 Is a future Sino-American war probable or not? If it began, would it likely be started by China as a rising power, or by America as a declining hegemon?

2 Many theorists of power transitions have seen the twentieth century's world wars as conflicts started by Germany seeking to replace Britain as a world hegemon. Contemporary application of that paradigm suggests that America, while still strong, might muster resources to resist China's rising power. Steve Chan argues, however, that this version of power-transition theory is inaccurate as a description of the past and self-fulfilling as a prophesy of war. He likens the future Sino- American power shift to smoother transitions, such as that from Britain to the US.

3 Although "officials and scholars construct realities (...) the U.K. chose to appease the U.S. and oppose Germany." Chan suggests Britain's motives were not cultural: "The argument for [Anglo-American] affinity will hardly suffice to explain London's decision to recruit Japan as a junior partner in the Asia Pacific during the late 1800s (...)" (p. 4). He claims that Germany's main fears in the 1910s and 1930s were of a rising Russia, and that Berlin's efforts to keep London (and then Washington) neutral failed when smaller allies' interests in war trumped the interests of larger powers in peace. Tails wag dogs before major conflicts.

Chan suggests that rising states are rational enough not to go to war merely because of past humiliations or current regime-type differences. Instead, they become violent when they expect the result of war may be a net gain for them. "Wars happen because there are discrepancies between states' power shares and their benefit shares" among either newcomers or hegemons. Danger arises when national leaders believe they do not receive a "ffair' share of benefits in proportion to their power" (p. 75). For example, 
if a dissatisfied state has prospered from exports (as China has, at least until 2009), a keen sense of past insults may shape rhetoric without creating violence.

Chan predicts that a Sino-American power transition "is unlikely to materialize in the next three or so decades at the earliest, if at all" (p. 9). Taiwan, if it declared independence, could threaten this peace. But Chan expects (and joins this reviewer in hoping) that American policy can avoid a war by continuing to assure both Beijing and Taipei that the US will not defend such a declaration.

6 To make his critique, Chan parses both logical categories and empirical evidence. While commending Chan's variety of styles of argumentation, this reviewer prefers the specific histories to the incorporeal logics. It is possible to object to some of the ways the book mixes them. For example, Chan notes that most power-transition theorists in Germany before either world war saw the US as a non-central contender in world politics because of Berlin's overly exclusive attention to the European continent. But it might be simpler to say that Berlin underestimated the reactions of both London and Washington and overestimated Germany's power. Greater immunity to the lure of the abstract could lead a writer to express more direct hope that Beijing does not act externally until its power is enough for peaceful Chinese success.

7 To take another example, it is hard to estimate the truth of a sentence such as "A severe sense of insecurity, rather than overconfidence, was the impetus behind Japan's military planning [before Pearl Harbor]" (p. 56). Insecurity and overconfidence are both documentable as factors in this mistake. Social scientists, including many whom Chan rightly criticises, tend to like the kind of monocausal explanation that could have been avoided here.

8 Chan organises a convincingly full panoply of historical similes and theorised causations (including several versions of realism, institutionalism, and constructivism). To make a long story short, he concludes as an optimist. Big wars can occur when rising powers underestimate extended deterrence by hegemons that do not make their interests clear. But Chan does not think this will happen any time soon in the SinoAmerican case, where both major powers are nuclear, and where the most relevant deterrence is of an attack on Taiwan, presuming the island does not legally renounce its option to be part of China.

9 The danger of Sino-American war would come from US indecision over whether to deter a conflict if it could, or to make concessions if it could not. Chan says the PRC's neighbours, including Taiwan, are more likely to engage China's prosperity than resist it. He argues that if China receives adequate net benefits from its overall relations with America, there will be peace. He guesses that "current trends favour an eventual settlement of Taiwan's status" (p. 119). Severe economic depression, more nationalist definitions of "benefit" among Beijing leaders, and/or a resurgence of Taiwanese nationalism might suggest less optimism-but Chan suggests that politicians can continue to avert a war.

10 This reviewer guesses Chan is right, even though some of his interpretations are expressed in unnecessarily complex forms. He claims, "For a policy of pivotal deterrence to be credible, Taipei must be made to believe that Washington does not really intend to abandon it should it declare formal independence" (p. 101). This sentence depends on an involuted discussion of differences between "pivotal" and "extended" deterrence, but that framework omits consideration of factors such as American naval capabilities or internal politics in Taiwan or the PRC-and after Chan 
introduces such factors, the discourse becomes convincing. Some theory is always needed before empirical data are gathered, but Chan is all too faithful to contemporary political science on the unusual occasions when he puts deduction prior to induction without noting the iterative feedback between them.

Important prospective readers of this book are in China. Some, apparently including the Peking University Dean Wang Jisi, would believe Chan's opinion that no power transition may take place soon. Their foreign policy is thus careful. But the most important readers of the book are American, if they see Chan's evidence that declining hegemons (often spurred to war by much smaller allies) have made crucial decisions that led to world wars.

12 A power transition point is evidenced if one nation's power surpasses that of another. Yet there are big problems with criteria such as a "composite index of national capability," which has been used by researchers in the Correlates of War Project, and also with criteria developed by the CIA and others. Chinese social scientists such as Tsinghua Professor Yan Xuetong have been avid surveyors of national power, and Yan includes a subjective factor: the degree of will to use objective capabilities. "Soft" cultural power has also been subject to surveys: numbers of tourists or foreign students or movies. Dangers of unnecessary tragic war lurk in the wide grey-area ranges (not points) in which asymmetric conflict is possible and the crossover of effective power is uncertain.

13 A problem of power-transition theory, which Chan mentions but does not stress, is that power is meaningless when separated from the goals for which it is exerted. The current global "superpower" has not been all that super in places such as Somalia, or in serving its own interests in the Middle East. Chan's criticisms of power transition are cogent, and he might have extended them by stressing that it is hard to interpret measures of power abstracted from its purposes.

14 Critiques of this critique are possible, therefore. But Chan has written a carefully circumspect book about a global issue of the utmost importance. This book is like a crash course in both international relations theory and Sino-American security relations. It is highly recommended to anybody who is interested in either China or peace.

\section{AUTHOR}

\section{LYNN T. WHITE}

Professor of Politics and International Affairs at Princeton University 